\title{
DNA BARCODING DAN STATUS KONSERVASI IKAN HIU (HEMISCYLLIIDAE DAN CHARCHARHINIDAE) YANG DIDARATKAN DI PPN SUNGAILIAT BANGKA
}

\author{
Risna Hidawatia ${ }^{\text {, Okto Supratman }}{ }^{\mathrm{a}}$, Ahmad Fahrul Syarif ${ }^{\mathrm{b}}$, Siti Aisyah ${ }^{\mathrm{a}^{*}}$ \\ aJurusan Manajemen Sumberdaya Perairan, Fakultas Pertanian Perikanan dan Biologi \\ Universitas Bangka Belitung \\ bJurusan Akuakultur, Fakultas Pertanian Perikanan dan Biologi, Universitas Bangka Belitung \\ *Koresponden penulis: sitiaisyahsa057@gmail.com
}

\begin{abstract}
Abstrak
Ikan hiu merupakan ikan bertulang rawan yang banyak diburu karena memiliki nilai ekonomi yang tinggi. Penangkapan dan perdagangan secara berlebihan menyebabkan spesies ini terancam kepunahan dan sudah masuk dalam beberapa ketegori IUCN Red List. Informasi mengenai jenis-jenis hiu yang didaratkan di PPN Sungailiat Bangka masih sangat terbatas dikarenakan sulitnya identifikasi secara morfologi sehingga perlu dilakukan identifikasi dengan metode molekuler. Penelitian ini bertujuan untuk mengetahui jenis, filogenetik dan status konservasi ikan hiu yang didaratkan di PPN Sungailiat Bangka. Penelitian dilakukan pada Januari - Agustus 2019. Metode penelitian terdiri dari empat tahap, yaitu pengumpulan sampel, identifikasi molekuler (gen Cytochrome Oxidase Subunit 1/COI), analisis filogenetik dan status konservasi. Hasil penelitian menunjukan bahwa karakter nukleotida gen COI sampel ikan hiu yang dicocokan dengan menggunakan program BLAST yang terintegrasi pada laman GenBank teridentifikasi sebagai spesies Chiloscyllium punctatum dan Carcharhinus leucas dengan tingkat kemiripan masing-masing 100\%. Jika ditinjau dari data IUCN Red List, spesies Chiloscyllium punctatum dan Carcharhinus leucas masuk dalam kategori Near threatened (Hampir Terancam). Pendataan jenis dan status konservasi ikan hiu ini merupakan salah satu langkah awal dalam pengelolaan mengingat spesies tersebut berperan penting dalam keseimbangan ekosistem laut.
\end{abstract}

Keywords: DNA barcoding, ikan hiu, status konservasi, PPN Sungailiat, Bangka

\begin{abstract}
Sharks are cartilage fish that is hunted because it has high economic value. Excessive capture and trade put this species at risk of extinction and have been included in several IUCN Red List categories. Information about the species of sharks landed in PPN Sungailiat Bangka is still very limited due to the difficulty of morphological identification, so identification needs to be done with molecular method. This study aims to determine the species, phylogenetic analysis and conservation status of sharks landed in PPN Sungailiat Bangka. The study was conducted in January - August 2019. The research method consisted of four stages, sample collection, molecular identification (gene Cytochrome Oxidase Subunit 1/ COI), phylogenetic analysis and conservation status. The results showed that the COI gene nucleotide characteristics of shark samples matched using the integrated BLAST program on the GenBank page were identified as species of Chiloscyllium punctatum and Carcharhinus leucas with $100 \%$ similarity respectively. When viewed from the IUCN Red List data, the species Chiloscyllium punctatum and Carcharhinus leucas belong to thecategory Near threatened. The data collection on the type and status of shark conservation is one of the first steps in management considering that these species play an important role in the balance of the marine ecosystem.
\end{abstract}

Keywords: DNA Barcoding, shark fish, conservation status, PPN Sungailiat, Bangka

\section{PENDAHULUAN}

Provinsi Kepulauan Bangka Belitung merupakan kepulauan yang memiliki letak geografis berbatasan dengan Selat Bangka di sebelah barat, Selat Karimata di sebelah timur, Laut Natuna di sebelah utara dan Laut Jawa di sebelah selatan. Provinsi ini terbagi atas 2 
pulau besar utama yaitu Pulau Bangka dan Pulau Belitung yang sekitarnya dikelilingi oleh pulau-pulau kecil [1]. Wilayah ini memiliki potensi sumber daya perikanan yang cukup tinggi. Salah satunya dari sektor perikanan tangkap, banyak masyarakat yang memanfaatkan sumber daya perikanan tangkap untuk memenuhi kebutuhan hidup. Hasil tangkapan yang didapatkan juga beragam baik hasil tangkapan utama maupun sampingan, salah satu jenis dari hasil tangkapan sampingan adalah ikan hiu. Ikan hiu hasil tangkapan nelayan ini bisa ditemui di beberapa tempat pendaratan ikan salah satunya Pelabuhan Perikanan Nusantara (PPN) Sungailiat, Kabupaten Bangka. Menurut data produksi ikan dominan PPN Sungailiat tahun 2018 jumlah seluruh produksi perikanan berjumlah $4.936 .332 \mathrm{~kg}$, dan khusus untuk ikan hiu budu jumlah produksi sekitar 10.547 $\mathrm{kg}$ dan hiu punai $5.517 \mathrm{~kg}$.

Ikan hiu merupakan ikan bertulang rawan dari sub kelas Elasmobranchii. Indonesia memiliki keragaman jenis hiu yang cukup tinggi, setidaknya 117 jenis ikan hiu yang termasuk ke dalam 25 marga ditemukan di wilayah perairan Indonesia [2][3][4] dari keseluruhan jenis tersebut, sekitar 26 jenis hiu dari 10 marga dan enam suku memiliki nilai ekonomi tinggi untuk diperdagangkan siripnya di pasaran nasional maupun internasional. Hampir seluruh bagian tubuh hiu dapat dijadikan komoditi, dagingnya dapat dijadikan bahan pangan bergizi tinggi, siripnya untuk ekspor dan kulitnya dapat diolah menjadi bahan industri kerajinan kulit berkualitas tinggi, serta minyak hiu sebagai bahan baku farmasi atau untuk ekspor. Tanpa kecuali gigi, empedu, isi perut, tulang, insang dan lainnya masih dapat diolah untuk berbagai keperluan seperti bahan lem, ornamen, pakan ternak, bahan obat dan lain-lain [5]

Namun, pada umumnya perdagangan ikan hiu hanya dilakukan dalam bentuk sirip sehingga sulit untuk diidentifikasi secara konvensional untuk mengetahui jenis hiu apa saja yang lebih banyak dimanfaatkan, khususnya di Pulau Bangka. Keberadaan metode DNA barcoding diperkenalkan sebagai sarana untuk mengidentifikasi semua spesies hewan. Kemampuan barcode DNA untuk mengidentifikasi spesies bergantung pada degenerasi kode genetik. Taksonomi molekuler DNA barcoding dapat membantu proses identifikasi karena hanya membutuhkan sedikit jaringan tubuh dari ikan tersebut [6].

Identifikasi jenis menggunakan metode identifikasi molekuler sangat diperlukan, mengingat minimnya data dan informasi serta sulitnya identifikasi jenis hiu secara morfologi dikarenakan beberapa jenis hiu hasil tangkapan yang didaratkan di Pelabuhan Perikanan Nusantara (PPN) Sungailiat Kabupaten Bangka telah dipersiapkan untuk dikemas dalam proses ekspor sehingga waktu untuk pengamatan sangat terbatas. Identifikasi molekuler tersebut dilakukan sebagai upaya basis data jenis-jenis ikan hiu untuk mengetahui status konservasi terhadap kelompok Elasmobranchii yang sebagian sudah masuk dalam daftar merah (red list) IUCN yang harus dilindungi dan dilakukan pengelolaan. Penelitian ini bertujuan untuk mengetahui jenis-jenis ikan hiu, filogenetik dan status konservasi ikan hiu yang didaratkan di Pelabuhan Perikanan Nusantara Sungailiat Bangka.

\section{METODE PENELITIAN}

\section{Waktu dan Tempat}

Penelitian dilaksanakan pada bulan Januari sampai Agustus 2019 di Pelabuhan Perikanan Nusantara Sungailiat, Kabupaten Bangka dan Laboratorium Tropical Marine Biotechnology Universitas Diponegoro dan Laboratorium Molekuler Balai Karantina Ikan Pangkalpinang untuk identifikasi molekuler. Pengambilan sampel pada penelitian ini menggunakan metode purposive sampling, salah satu teknik yang dilakukan berdasarkan pertimbangan peneliti. Dalam penelitian ini, sampel yang diperoleh disesuaikan dengan kondisi keberadaan/kehadiran sampel ikan hiu yang didaratkan di PPN Sungailiat. 

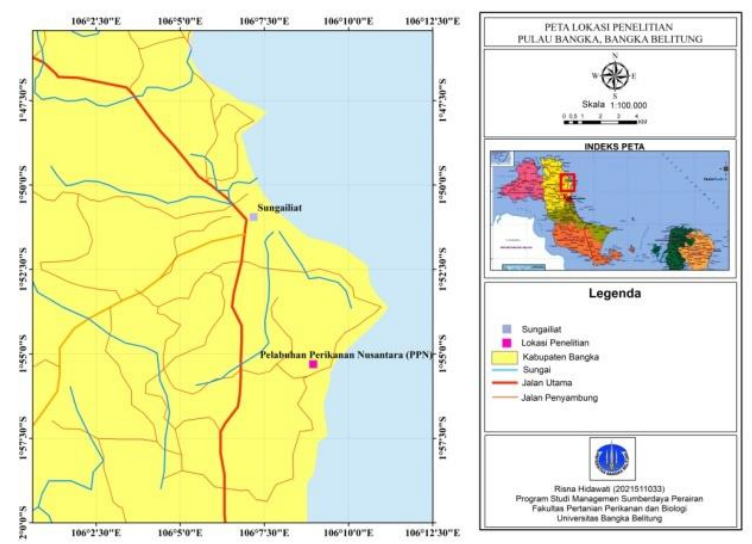

Gambar 1. Peta Lokasi Pengambilan Sampel di PPN Sungailiat Bangka

\section{Identifikasi Molekuler}

Identifikasi molekuler dimulai pada proses destruksi dan ekstraksi DNA yang bertujuan untuk menghancurkan sel dan mengambil jaringan pada sampel hiu tersebut. Metode ekstraksi yang digunakan mengikuti metode DNA KIT Tissue yang terdiri dari tahap lysis, binding, washing dan elution. Hasil proses ekstraksi kemudian disimpan pada suhu $-20^{\circ} \mathrm{C}$. Proses amplifikasi DNA menggunakan metode Polymerase Chain Reaction (PCR), yang merupakan suatu teknik perbanyakan (replikasi) DNA secara enzimatik. Primer yang digunakan untuk hiu adalah Primer Forward FishF2_tl (5'-TGT AAA ACG ACG GCC AGT CGA CTA ATC ATA AAG ATA TCG GCA C3') dan Primer Reverse FishR2_tl (5'-CAG GAA ACA GCT ATG ACA CTT CAG GGT GAC CGA AGA ATC AGA A3') [7].

Proses PCR pada penelitian ini dilakukan sebanyak 35 kali siklus dan setiap siklus terdiri atas tiga tahap, yaitu denaturasi awal pada suhu $95^{\circ} \mathrm{C}$ selama 1 menit, denaturasi pada suhu $95^{\circ} \mathrm{C}$ selama 15 detik, annealing pada suhu $48-55^{\circ} \mathrm{C}$ selama 15 detik, ekstensi pada suhu $72^{\circ} \mathrm{C}$ selama 10 detik, dan ekstensi akhir pada suhu $72^{\circ} \mathrm{C}$ selama 10 menit (perlakuan suhu telah disesuaikan peneliti) [8].

Elektroforesis adalah teknik pemisahan komponen atau molekul bermuatan berdasarkan perbedaan tingkat migrasinya dalam sebuah medan listrik. Elektroforesis bertujuan untuk mengetahui kualitas DNA dalam produk PCR. Fragmen DNA dengan panjang yang berbeda divisualisasikan menggunakan pewarna fluorescent spesifik untuk DNA, seperti bromida etidium. Jenis gel yang digunakan adalah agarosa yang dapat menunjukkan band atau ukuran fragmen pasangan basa yang dapat dilihat dengan sinar ultraviolet [9].

Proses sekuensing DNA dilakukan untuk menentukan urutan nukleotida yang terdapat dalam DNA. Urutan DNA berhubungan dengan informasi genetik turunan dalam nukleus (inti), plasmid, mitokondria, dan kloroplas yang membentuk dasar pengembangan semua makhluk hidup. Sampel yang sudah diamplifikasi dengan metode PCR, selanjutnya disekuensing untuk memperoleh urutan nukleotidanya [9].

\section{Penyusunan DNA Consensus}

Penyusunan DNA consensus menggunakan software MEGA7 (Molecular Evolutionary Genetic Analysis), yang meliputi; proses trimming, reverse compliment dan alignment. Analisis ini dilakukan untuk pembacaan urutan nukleotida dan penjajaran (alignment) menggunakan Muscle untuk mendapatkan hasil yang lebih akurat. Data hasil penjajaran nukleotida yang diperoleh kemudian dicocokkan dengan data yang tersedia pada GeneBank di NCBI (National Center for Biotechnology Information) dengan menggunakan fasilitas nucleotida BLAST (Basic Local Alignment Search Tool).

\section{Analisis Filogenetik}

Filogenetik adalah salah satu sistem klasifikasi yang didasarkan pada hubungan kekerabatan (evolusi) antara takson satu dengan lainnya [10]. Oleh karena itu sistem klasifikasi ini sangat penting untuk digunakan dalam penelusuran kekerabatan evolusioner diantara berbagai takson yang ada [11]. Pembuatan rekonstruksi filogenetik pada 
penelitian ini menggunakan metode Neighbour-joining tree.

\section{Penentuan Status Konservasi}

Hasil yang diperoleh dari identifikasi molekuler kemudian ditentukan status konservasinya dengan menggunakan pedoman IUCN (International Union for Conservation of Nature and Natural Resources). Kategori status IUCN Red List merupakan kategori yang digunakan oleh IUCN dalam melakukan klasifikasi terhadap spesies-spesies berbagai makhuk hidup yang terancam kepunahan.

\section{HASIL DAN PEMBAHASAN}

\section{Identifikasi Molekuler}

Sampel ikan hiu yang didapatkan dari sumber pendaratan ikan yang potensial di PPN Sungailiat Kabupaten Bangka kemudian dibawa ke laboratorium untuk diidentifikasi secara molekuler. Berikut hasil visualisasi sampel ikan hiu yang telah diamplifikasi menggunakan teknik PCR:

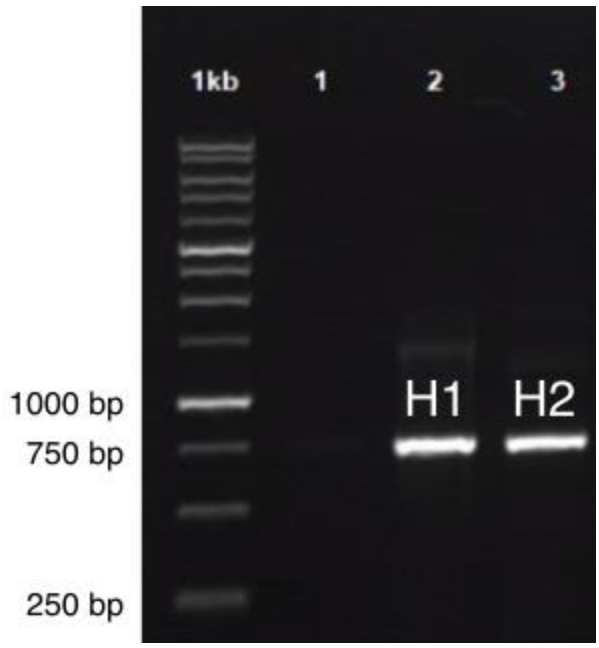

Gambar 2. Hasil amplifikasi gen COI sampel ikan hiu dengan gel agarose $1 \%$

Keterangan:

H1: Kode sampel ikan hiu ke-1

H2: Kode sampel ikan hiu ke-2

Hasil PCR menunjukkan adanya pita DNA pada masing-masing lintasan sampel DNA ikan hiu yang teramati pada posisi panjang amplikon sekitar 600-700 bp dengan menggunakan ukuran $1 \mathrm{~kb}$ DNA ladder sebagai pembanding (Gambar 2). Ukuran panjang amplikon ikan hiu pada penelitian ini sama dengan penelitian yang dilakukan oleh Ward dan Holmes (2007) dan Wynen et al (2009) yang memperoleh ukuran urutan basa ikan hiu sekitar 655 - 700 bp [12][13].

Proses identifikasi molekuler ikan hiu dilanjutkan pada tahap sekuensing untuk mengetahui susunan basa sampel tersebut. Hasil sekuensing pada kedua sampel ikan hiu untuk sampel H1 diperoleh urutan basa 659 kode DNA dan untuk sampel $\mathrm{H} 2$ diperoleh 666 kode DNA (Tabel 1).

Table 1. Urutan basa nukleotida ikan hiu >UBBMSP_H1_Fish

GCATGAGCAGGAATAGTAGGTATAGCTCTTAG CCTTTTAATCCGCGCTGAATTAAGTCAACCTGG ATCCCTTCTAGGTGATGATCAGATTTATAATGT AATCGTAACAGCCCATGCTTTTGTAATAATTTT CTTTATAGTAATGCCTGTAATAATTGGTGGATT TGGAAATTGACTAGTACCCCTAATAATTGGTGC GCCTGATATAGCCTTTCCTCGAATAAACAATAT AAGCTTTTGATTACTTCCTCCTTCATTCCTATTA CTTTTAGCCTCTGCAGGAGTTGAAGCCGGAGC AGGAACAGGGTGAACTGTTTACCCACCTTTAG CAGGTAATTTAGCCCACGCAGGAGCATCAGTT GATTTAACTATTTTCTCCTTACACTTAGCAGGA ATTTCATCAATCCTAGCCTCTATCAATTTCATC ACAACCATTATCAATATAAAACCACCAGCCAT TTCTCAATATCAAACACCCTTATTTGTATGATC AATTCTTGTAACTACCATCCTTCTACTTCTTTCA TTACCAGTTCTAGCAGCAGGTATTACTATATTA CTTACAGATCGAAACCTAAATACAACATTCTTT GATCCAGCAGGAGGAGGCGATCCTATTTTATA TCAACACCTATTCTGATTCTTCGGTCACCCTGA AGT

>UBBMSP_H2_Fish

GTGCATGAGCAGGTATAGTTGGTACAGCCCTA AGTCTCCTAATTCGAGCTGAACTTGGACAACCT GGATCACTTTTAGGAGATGATCAGATCTATAAT GTAATCGTAACTGCCCACGCTTTTGTAATAATC TTTTTCATAGTTATACCAATTATAATTGGTGGT TTCGGAAATTGATTAGTTCCTTTAATAATTGGT GCACCAGACATAGCCTTTCCACGAATAAATAA CATAAGTTTCTGACTTCTTCCACCATCATTTCTT CTTCTCCTCGCCTCTGCTGGAGTAGAAGCTGGA GCAGGTACTGGTTGAACAGTCTATCCTCCATTA GCTAGCAATCTAGCACATGCTGGGCCATCTGTT GACTTAGCTATCTTCTCCCTTCACTTAGCTGGT GTTTCATCAATTTTAGCTTCAATTAATTTTATTA CAACTATTATTAATATAAAACCACCAGCCATTT CCCAATATCAAACACCATTATTTGTTTGATCCA TTCTTGTAACCACTATTCTTCTTCTCCTCTCACT CCCAGTCCTTGCAGCAGGGATTACAATATTACT TACAGATCGTAACCTTAATACTACATTCTTTGA 
TCCTGCAGGTGGAGGAGACCCAATCCTTTATC AACACTTATTCTGATTCTTCGGTCACCCTGAAG TGTCAT

Hasil sekuensing berupa urutan basa dianalisis menggunakan database GenBank yang berada di bawah NCBI (National Center for Biotechnology Information). Database tersebut merupakan database primer yang menampung semua urutan DNA yang didepositkan oleh para peneliti dari seluruh dunia. Teknik pencarian berdasarkan kekerabatan antar data menggunakan program pencari yang terdapat dalam data Base tersebut. Dua program yang banyak digunakan adalah Basic Local Alignment Search Tool (BLAST) dan FASTA. Dari program tersebut diperoleh bahwa sekuensing sampel ikan hiu dengan kode sampel H1 memiliki tingkat kemiripan 100\% dengan famili Hemiscylliidae yaitu spesies Chiloscyllium punctatum (Hiu Bambu), dan sampel $\mathrm{H} 2$ memiliki tingkat kemiripan sebesar $100 \%$ dengan famili Carcharhinidae yaitu spesies Carcharhinus leucas (Hiu Banteng). Persentase tingkat kemiripan dari kedua spesies ini menunjukkan bahwa pengidentifikasian spesies menggunakan DNA molekuler sangat sesuai.

Tabel 2. Nama Spesies dan Presentasi similarity

\begin{tabular}{lccc}
\hline Kode Sampel & \multicolumn{1}{c}{ Spesies } & \% Query Cover & \% Per. Ident \\
\hline UBBMSP_H1_Fish & Chiloscyllium punctatum & $96 \%$ & $100 \%$ \\
UBBMSP_H2_Fish & Carcharhinus leucas & $95 \%$ & $100 \%$ \\
\hline
\end{tabular}

\section{Analisis Filogenetik}

Hasil analisis pohon filogenetik menggunakan metode Neighbour-joining tree. Rekonstruksi tersebut menunjukkan bahwa hiu yang didaratkan di PPN Sungailiat Bangka terbagi kedalam 2 famili yaitu Hemiscyllidae dan Carcharhinidae, yang membentuk 2 kelompok (Cluster) sesuai dengan familinya. Pohon filogenetik memperlihatkan bahwa hasil analisis BLAST sesuai dengan karakteristik cabang yang dibentuk oleh pohon filogenetik. Semakin banyak urutan nukleotida (sekuen) yang sama maka nilai similaritasnya akan semakin tinggi sehingga posisinya di dalam percabangan pohon filogenetik akan semakin berdekatan [14].

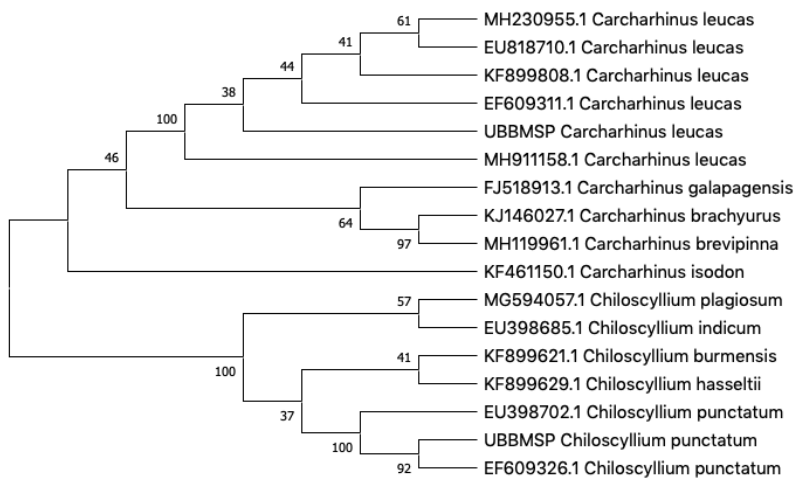

Gambar 3. Pohon filogenetik sampel ikan hiu UBBMSP_H1 dan UBBMSP_H2 yang didaratkan di PPN Sungailiat

Konstruksi pohon filogenetik hiu menunjukkan bahwa kelompok pertama ditempati oleh famili Carcharhinidae dengan hiu jenis Carcharhinus leucas. Hiu jenis Carcharhinus leucas terletak pada satu pohon karena memiliki sekuen yang sama sehingga memiliki hubungan kekerabatan yang tinggi dengan nomor kode akses pada GeneBank MH230955.1. Kelompok yang kedua ditempati oleh famili Hemiscyllidae yaitu hiu dengan jenis Chiloscyllium punctatum. Hiu jenis Chiloscyllium punctatum terletak pada satu pohon karena memiliki sekuen yang sama sehingga memiliki hubungan kekerabatan yang 
tinggi dengan nomor kode akses pada GeneBank EF609326.1.

The evolutionary relationships of taxa dianalisis dengan menggunakan metode Neighbour-joining [15]. Pohon optimal dengan panjang cabang yang ditampilkan = 0.45493455 . Persentase pohon replikasi dimana setiap taksa yang terkait akan ber-cluscter dalam tes bootstrap (1000 ulangan) yang ditampilkan di sebelah cabang [16]. Jarak evolusi dihitung dengan menggunakan metode Kimura 2-parameter [17] dan berada dalam unit jumlah substitusi dasar per-site. Analisis melibatkan 17 urutan nukleotida. Ada sekitar 655 posisi dalam data set terakhir. Analisis evolusi ini dilakukan dengan menggunakan MEGA X [18] [19].

\section{Status Konservasi}

Menurut IUCN redlist 2001 hiu jenis Chiloscyllium punctatum dan hiu jenis Carcharhinus leucas masuk dalam kategori Hampir Terancam (Near threatened), kategori ini diberikan kepada jenis yang diyakini akan terancam keberadaannya di masa mendatang, dan apabila tidak ada usaha pengelolaan terhadap jenis tersebut.

Faktor-faktor yang dapat memengaruhi kepunahan hiu yaitu tingginya penangkapan terhadap jenis tersebut tidak sebanding dengan laju reproduksi dan pertumbuhan kedua jenis tersebut terutama pada hiu. Ada beberapa faktor yang memengaruhi yaitu hiu memiliki siklus hidup yang panjang untuk mencapai usia dewasa dan kemampuannya untuk bereproduksi sangat rendah. Pada beberapa kondisi tertentu, hiu tidak sengaja tertangkap oleh nelayan atau disebut dengan incidental take, dalam kondisi lemah atau mati hiu kemudian dibuang kembali ke lautan tanpa harapan hidup. Hal inilah yang menyebabkan tingkat kematian hiu sangat tinggi, serta terjadi penurunan kualitas areal pembesaran ikan dan daerah-daerah pantai, estuari maupun air tawar akibat pembangunan, over-eksploitasi dan pencemaran sehingga mengganggu kelangsungan hidup hiu [20]
Adapun beberapa rekomendasi dalam upaya pengelolaan hiu berdasarkan hasil simposium hiu dan pari di Indonesia yang sebagai berikut: Perlunya melakukan pendataan hasil tangkapan yang baik untuk dapat mengestimasi stok dan status populasi hiu di Indonesia; Mengidentifikasi dan menentukan lokasi prioritas pendataan hiu di wilayah prioritas potensial, dan identifikasi lokasi berdasarkan data statistik perikanan, target penangkapan, alat penangkap ikan, dan daerah penangkapan; Membentuk kelompok kerja perikanan hiu yang salah satu tugas utamanya adalah mengelola data dan informasi perikanan hiu yang dikumpulkan oleh para pihak terkait; Memperkuat sistem ketelusuran (traceability) produk baik untuk pasar ekspor dan domestik; Menginisiasi wilayah percontohan dalam membangun sistem ketelusuran pasar domestik untuk perikanan hiu [21].

Berdasarkan Rencana Aksi Nasional (RAN) mengenai Konservasi dan Pengelolaan Hiu dan Pari 2016 - 2020 terdapat beberapa regulasi internasional dan nasional dalam upaya pengelolaan hiu dan pari. Regulasi internasional terdiri dari Indian Ocean Tuna Commission (IOTC), Commission for the Conservation of Southern Bluefin Tuna (CCSBT), Western and Central Pasific Fisheries Commission (WCPFC), Inter American Tropical Tuna Commission (IATTC), Convention on International Trade in Endangered Species (CITES). Semua regulasi internasional di atas mengatur tentang pengelolaan hiu dan pari, salah satu ketentuannya yaitu setiap kapal penangkap dilarang untuk menyimpan di atas kapal, memindahkan dari/ke kapal lain atau mendaratkan tangkapan sirip ikan hiu. Sedangkan ditingkat nasional sendiri, Indonesia memiliki beberapa regulasi yang dikeluarkan sebagai upaya pengelolaan hiu dan pari, diantaranya PP Nomor 7 Tahun 1999 tentang konservasi sumber daya alam hayati dan ekosistemnya, Permen Kelautan dan Perikanan Nomor 57/PERMEN-KP/2014 tentang usaha perikanan tangkap di wilayah pengelolaan perikanan Republik Indonesia, SK Menteri 
Kelautan dan Perikanan Nomor 18/KEPMEN$\mathrm{KP} / 2013$ tentang penetapan status perlindungan ikan hiu paus (Rhincodon typus) dengan status perlindungan penuh, SK Menteri Kelautan dan Perikanan Nomor 4/KEPMEN-KP/2014 tentang penetapan status perlindungan penuh pari manta (Manta spp.), dan PERMEN Kelautan dan Perikanan Nomor 59/PERMEN-KP/2014 tentang larangan pengeluaran hiu koboi dan hiu martil [22].

\section{KESIMPULAN}

Hasil identifikasi molekuler dan konstruksi pohon filogenetik dari urutan basa nukleotida menunjukkan sampel ikan hiu yang didaratkan di PPN Sungailiat Bangka terbagi ke dalam 2 spesies dengan 2 famili berbeda, yaitu famili Hemiscyllidae dengan spesies Chiloscyllium punctatum (Hiu Bambu), dan family Carcharhinidae dengan spesies Carcharhinus leucas (Hiu Banteng). Ditinjau dari status konservasinya, kedua spesies hiu tersebut masuk ke dalam kategori hampir terancam (NT) dalam redlist IUCN.

\section{UCAPAN TERIMA KASIH}

Terima kasih kepada Jurusan Manajemen Sumber daya Perairan Universitas Bangka Belitung. PPN Sungailiat Kabupaten Bangka, Laboratorium Tropical Marine Biotechnology Universitas Diponegoro dan Laboratorium Molekuler Balai Karantina Ikan Pangkalpinang.

\section{DAFTAR PUSTAKA}

[1] Dinas Kelautan dan Perikanan Provinsi Kepulauan Bangka Belitung. 2005. Laporan Tahunan 2004. Pangkal Pinang: Dinas Kelautan Perikanan. $32 \mathrm{hlm}$.

[2] Fahmi dan Dharmadi. 2013. Pengenalan Jenis-jenis hiu di Indonesia. Direktorat Konservasi Kawasan dan Jenis Ikan, Kementrian Kelautan dan Perikanan. 63 hal.

[3] Fahmi dan Dharmadi. 2014. First confirmed record of the white shark Carcharodon carcharias (Lamniformes:
Lamnidae) from Indonesia. Marine Biodiversity Records, Vol.7, e53:1-3.

[4] Fahmi and W.T White. 2015. First record of the basking shark Cetorbinus maximus (Lamniformes: Cetorhinidae) in Indonesia. Marine Biodiversity Records, Vol. 8, e18:1-3

[5] Wibowo, S. dan Susanto, H. 1995. Sumberdaya dan Pemanfaatan Hiu. Jakarta: Penebar Swadaya.

[6] Hebert, P.D.N., Cywinska, A., Ball, S.L., deWaard, J.R. 2003. Biological identifications through DNA barcodes, Proc, R.Soc.B 270: 313-321.

[7] Ward R.D., T.S. Zemlak, B.H. Innes, P.R. Last, and P.D.N. Hebert. 2005. DNA barcoding Australia's fish species. Philosophical Transactions of the Royal Society B Biological Sciences, 360(1462):1847-57.

http://dx.doi.org/10.1098/rstb.2005.1716.

[8] Eugene H.K.W., S.S. Mahmood, and H.H. Robert. 2009. Identifying sharks with DNA barcodes: assessing the utility of a nucleotide diagnostic approach. Molecular Ecology Resources (Suppl. 1). 243-256. http://dx.doi.org/10.1111/j.17550998.2009.02653.x.

[9] Kurniasih, E.M. 2013. DNA Barcoding dan Analisis Filogenetik Ikan Hiu yang didaratkan di Pelabuhan Perikanan Samudera Cilacap. Departemen Ilmu dan Teknologi Kelautan. Fakultas Perikanan dan Ilmu Kelautan. Institut Pertanian Bogor.

[10] Purnomo dan Pudjoarinto, A. 1999. Struktur Perkembangan I (Morfologi Tumbuhan). Fakultas Biologi UGM. Yogyakarta, hal.1-3.

[11] Mabrouk, M.S., Hamdy, M., Mamdouh, M., Aboelfotoh, M. dan Kadah, Y.M. 2006. BIOINFTool: Bioinformatics and sequence data analysis in molecular biology using Matlab. Proc. Cairo International Biomedical Engineering Conference. 
[12] Ward, R.D. and Holmes, B.H. 2007. An analysis of nucleotide and amino acid variability in the barcode region of cytochrome $c$ oxidase I (coxl) in fishes. Molecular Ecology Resourcs Journal, 7(6):899-907.

https://doi.org/10.1111/j.1471-

8286.2007.01886.x

[13] Wynen, L., Larson, H., Thorburn, D., Peverell, S., Morgan, D., Field, I., \& Gibb, K. (2009). Mitochondrial DNA supports the identification of two endangered river sharks (glyphis glyphis and glyphis garricki) across northern Australia. Marine and Freshwater Research, 60(6), 562. https://doi.org/10.1071/MF08201

[14] Rahmad. 2013. Taksonomi Molekuler 'DNA Barcoding' dan Analisis Filogenetik Ikan Hiu di Pelabuhan Perikanan Palabuhanratu Berdasarkan Marka Mitokondria. [Skripsi]. Departemen Ilmu dan Teknologi Kelautan. Fakultas Perikanan dan Ilmu Kelautan. Institut Pertanian Bogor.

[15] Saitou N. and Nei M. 1987. The neighbor-joining method: A new method for reconstructing phylogenetic trees. Molecular Biology and Evolution 4:406-425.

[16] Felsenstein J. 1985. Confidence limits on phylogenies: An approach using the bootstrap. Evolution 39:783-791.

[17] The evolutionary distances were computed using the Kimura 2-parameter method.
[18] Kumar S., Stecher G., Li M., Knyaz C., and Tamura K. 2018. MEGA X: Molecular Evolutionary Genetics Analysis across computing platforms. Molecular Biology and Evolution 35:1547-1549.

[19] Stecher G., Tamura K., and Kumar S. 2020. Molecular Evolutionary Genetics Analysis (MEGA) for macOS. Molecular Biology and Evolution (https://doi.org/10.1093/molbe $\mathrm{v} / \mathrm{msz} 312)$.

[20] Fahmi dan Dharmadi. 2005. Status Perikanan Hiu dan Aspek Pengelolaannya. Direktorat Konservasi Kawasan dan Jenis Ikan, Kementrian Kelautan dan Perikanan. hlm: 2.

[21] Darwanto, Hatala, R., Dharmadi., Fahmi., Hadi, S., Ariyogagautama, D., Yuneni, R.R. 2016. Prosiding Simposium Hiu dan Pari di Indonesia. Kerjasama Kementerian Kelautan dan Perikanan, Lembaga Ilmu Pengetahuan Indonesia dan WWF Indonesia. Kementerian Kelautan dan Perikanan-2016. ISBN : 978-602-71086-2-2.

[22] Direktorat Konservasi dan Keanekaragaman Hayati Laut. 2015. Rencana Aksi Nasional (RAN) Konservasi dan Pengelolaan Hiu dan Pari 2016 - 2020. Ditjen Pengelolaan Ruang Laut. ISBN: 978-602-7913-28-4. 